UDC: 339.137.22

DOI 10.35433/ISSN2410-3748-2020-1(26)-7

JEL Classification: M210

Pavlovska Liudmyla

Ph.D., Professor

Department of Economics, Management and Marketing

Zhytomyr Ivan Franko State University

Ukraine

ORCID 0000-0002-6054-5884

\title{
PROVIDING COMPETITIVE ADVANTAGES AND BUSINESS BENEFITS
}

In the face of increased competition, one of the main means of promoting your business, strengthening competitive positions in the market is to demonstrate to consumers the advantages of the company, product or service and the benefits that they will receive as a result. It has been established that preferences are formed based on the characteristics of a product, service or company as a whole. The author believes that the benefits are derived from the benefits provided by the characteristic, they help the client solve their problem, make

life easier, save time, money or whatever is relevant to the buyer at the moment. The mechanism of generating business benefits is defined, which includes researching the demand of the target customer, the formation of competitive advantages, highlighting the benefits on their basis and demonstrating them to your customer.

It has been established that competitive advantages can be provided with the help of price, delivery time, experience, terms of cooperation, narrow specialization, business features, achievements, added value, responsibility for the goods (service), guarantees, demonstrations of offers, real customer reviews. Not all companies, especially young ones that are just entering the market, can compete with their competitors. To stay afloat, they have to inflate prices, extend the delivery time. In such cases, special techniques are used that

help to make advantages with the disadvantages. These are facts that counterbalance weaknesses. So, newly created companies usually have a small set of goods and services. In contrast to this argument, one can offer a statement about narrow specialization on a particular brand and the possibility of providing detailed advice on the specifics of the product. That is, the disadvantages that can lead the company to failure can become powerful competitive advantages that even firms already established in the market cannot provide.

Demonstration of competitive advantages is a fairly simple option to promote and position your name, does not require financial investments, but it is an effective tool for conducting competition.

Key words: competitive advantage, business, benefit, consumer, product, competitors, competition, service. 


\section{ЗАБЕЗПЕЧЕННЯ КОНКУРЕНТНИХ ПЕРЕВАГ ТА ВИГОД БІЗНЕСУ}

За умов посилення конкурентної боротьби одним із найвагоміших засобів просування свого бізнесу, посилення конкурентних позицій на ринку стає демонстрація споживачам переваг компанії, товару або послуги і вигод, які вони отримають в результаті. Встановлено, щуо переваги формуються, виходячи з характеристик товару, послуги або компанї в цүілому. Автор вважає, щчо вигоди є похідними переваги, забезпеченої характеристикою, щуо вони допомагають клієнту вирішувати їх проблему, полегшувати життя, економити час, гроші або те, щзо актуально для покупия в даний момент. Визначено механізм формування вигод бізнесу, який включає дослідження попиту цілььового покупчя, формування конкурентних переваг, виокремлення на їх основі вигод та демонстрація їх своєму покупщеві.

Встановлено, що конкурентні переваги можуть забезпечуватись ціною, термінами доставки, досвідом, умовами співпраці, вузькою спеціалізацією, особливостями бізнесу, досягненнями, додатковою иінністю, відповідальністю за товар (послугу), гарантією, демонстрачією пропозичії, реальними відгуками клієнтів. Не всі компанії, особливо молоді, які тільки виходять на ринок, можуть позмагатися зі своїми конкурентами. Щоб залишатися на плаву, їм доводиться завищувати ціни, продовжувати термін доставки. У таких випадках використовуються спеціальні прийоми, які допомагають з недоліків зробити переваги. Це факти, які стають противагою слабким місиям. Так, нещодавно створені компанії як правило мають невеликий набір товарів та послуг. У противагу иъьому аргументу можна запропонувати твердження про вузьку спеціалізацію на певному бренді та можливість надання детальної консультації щзоо специфіки товару. Тобто недоліки,

які можуть призвести компанію до провалу, можуть стати найпотужнішими конкурентними перевагами, які не здатні надати навіть вже усталені на ринку фірми.

Демонстрація конкурентних переваг є досить простим варіантом розкрутки $i$ позиціонування свого імені, який не вимагає фінансових вкладень, але при цььому $є$ ефективним інструментом для ведення конкурентної боротьби.

Ключові слова: конкурентна перевага, бізнес, вигода, споживач, товар, конкуренти, конкуренція, послуга.

Statement of the research problem. In conditions of intensified competition, modern business faces new challenges, among which an important place, along with creating a brand, developing a strategy for its promotion and development, positioning, is to ensure the competitive advantages of products, provide services and inform their consumers about it.

It is competitive advantages that help strengthen the company's position in the market; create prospects for sustainable growth and business continuity; create difficulties for competitors who enter the market. And, most importantly, competitive advantages are the main motivators for the consumer, which make him go for the actions that the business needs. It means that they bring the most 
income. The demanding buyer wants to trust the company, to be sure that having given his money, he can safely get what he expects. And it is important for any company to show its potential customer its own competitive advantages, convincing that it is precisely it that can satisfy its needs.

Analysis of recent research and publications. Theoretical and methodological principles of competition and competitiveness of enterprises were covered in their fundamental works by domestic and foreign researchers, in particular: G. Azoev, I. Ansoff, A. Andriychuk, L. Balabanov, I. Blank, S. Bru, A. Dementyev, B. Carloff, R. Campbell, M. Malik, A. Marshall, D. Mill, N. Moiseeva, F. Knight, M. Porter, D. Ricardo, J. Robinson, P. Samuelson, A. Smith, R. Fathutdinov, P. Heine, O. Shpychak, J. Schumpeter, A. Yudanov and others.

To date, a considerable amount of theoretical work has been presented in the field of the competitive advantages' nature by such authors as Ricardo, I. Kravis, J. Vanek, J.J. Lamben, M. Porter, K. Arrow, T. Levitt, W. Broll, S. Heimer, S. Kindleberger, W. Premier, X. Johnson, D. Teess, R. Kavs, R. Coase, P. Buckley, M. Casson, D. Dunning, M. Perlitz, G.L. Azoev, A.P. Chelenkov, V.K. Falzman, E.N. Winged, NI Fokin and others.

However, in modern economic conditions, a lot of new information has appeared on ensuring the competitive advantages of business, which requires new research and generalization. Recent events related to quarantine measures in connection with the coronavirus have made adjustments to the work of the business, which employers have not yet met. The dismissal of workers, the transition to remote work, the introduction of part-time work, taking into account the latest legislative changes, sending employees on various holidays this whole panoply of measures has become the modern life of employers and significantly affects the competitive advantage of the business. 
The purpose of the article is to substantiate theoretical and methodological principles and develop scientific and practical recommendations for ensuring the competitive advantages and benefits of business.

Statement of the main research material. The concept of competitive advantage contains the advantage of a company, product, service or brand over other existing market participants - competing companies working in one niche. So, the classic of competition M. Porter defines competitive advantage as a firm's position in the market, which allows it to overcome the forces of competition and attract customers [1, p.42]. J.J. Lamben understands competitive advantage as those characteristics, properties of a product or brand that create a certain superiority for a company over its direct competitors. These characteristics (attributes) can be very different and apply both to the product (service) itself, and to the additional services that accompany the basic one, to the forms of production, sales or sales specific to the company or product [2].

According to L. Azoev and A. P. Chelenkov, competitive advantages are understood as concentrated manifestations of superiority over competitors in the economic, technical and organizational fields of the enterprise; this can be measured by economic indicators (additional profit, higher profitability, market share, sales) [3, p. 41].

In modern business, this is often found as equivalent concepts of advantages and benefits. And it is important to indicate both benefits and benefits. And although they lead to a single result, they differ in value, so it is important to understand how, and also to know how and when to use them.

The benefits are based on the characteristics of the product, service or company as a whole. With their help, the client understands why and why the company is represented better and why it is better for him $[4,5]$.

Benefits are derived from the benefits provided by the characteristic. They help the client to solve their problem, make life easier, save time, money or whatever is relevant for the buyer at the moment. Despite the fact that the 
competitive advantages of the enterprise and the benefits in their specificity are different, they are united by common requirements. Namely: stand out from the competition; satisfy customer needs; be stable and unchanging in a changing market; be unique and make it clear that no other company will provide such advantages and benefits; work for the profit of the enterprise.

Competitive advantages should be based on the wishes of the target buyer, which must be studied. Once the benefits are formed, you can highlight the benefits on their basis and demonstrate to your customer. For example, in a smartphone repair company, we will find out the desires of customers and determine the advantages over competitors. What requirements can a client put on providing smartphone repair services? First of all, they are: the smartphone works without failures and glitches; the smartphone does not slow down or get warm; perhaps another condition for comfortable work with your smartphone. Along with this, the client, the recipient of the smartphones repair services, will have certain criteria regarding these services, namely: that it is not more expensive than the amount that he expects; so that the smartphone is repaired in 1-2 days; that original spare parts are installed; to give a guarantee for repair of at least 6 months; unwillingness to go to the service center on your own

Based on this, it is possible to form advantages:

- $\quad$ Smartphone repair from $50 \mathrm{UAH}$;

- $\quad$ Repair period - 1-2 days;

- $\quad$ Installing original spare parts. Do not use Chinese counterparts and fakes;

- Warranty for repairs -6 months;

- Courier delivery of the smartphone to the service center and to the client after its repair.

When certain benefits, you can go to the benefits:

- $\quad$ Save time - repair takes a maximum of 2 days; 
- Saving money - repairing a smartphone will cost $20 \%$ cheaper than in other service centers;

- $\quad$ Save energy - the courier will deliver the smartphone back and forth.

The formation and maintenance of a competitive advantage affects the entire the enterprise mechanism related to the creation, production and sale of products. The basic principles of the competitive advantages formation and support are: the enterprise management the desire to improve, innovate and change in all aspects of the enterprise's economic activity; improving and increasing the number of competitive advantage sources, contributes to the preservation of their activities and sustainability; application of a systematic approach to the formation of a competitive advantage, which covers the entire mechanism of the enterprise.

Often, opening a business where there are already many competing firms, it is considered that under such conditions it is difficult or impossible to single out competitive advantages. For example, enterprises selling consumer goods can develop such strong advantages that will set it apart from others.

Perhaps the most powerful advantage is the price. In this case, it is important to correctly format the information. Instead of template phrases: "Low price", "Discounts for regular customers", "Wholesale prices", "Prices from the manufacturer", etc., it is better to indicate in the language of numbers: " $20 \%$ discount on TVs", "prices are $25 \%$ lower market ".

Another advantage is delivery times. The client always wants to save his time. It is important to give him such an opportunity, indicating specific dates, and instead of the traditional phrase "fast delivery", write, for example, "delivery in one hour to any part of the city".

A valuable advantage can be information about the benefits that will help the consumer save their energy, time or increase their own productivity (for example, when applying for cleaning services, the client pays for cleaning and 
saves his energy by getting cleanness in his house). Such customer care arouses trust and motivates the consumer to act.

If experience is an advantage, phrases such as "we are experts in the field ..." should also be avoided. Much better option would be specific information about what has been done over 10 years of its activity. For example, opening 30 branches throughout the country and abroad, expanding production of new product lines, completing the construction of new workshops and the like.

Terms of cooperation, any of which may also be an important advantage of the business. This may be payment in cash or by bank transfer, which provides convenience to the buyer and therefore increases the chances of a sale; the possibility of producing goods on order, the geographical location of the office near the stop of municipal transport or the metro and the like. Even the possibility of shipment at own expense and your own warehouse or any information that gives the client the benefit of saving his time or effort, as a competitive advantage, can be useful by providing the buyer with maximum comfort.

If the company operates in a narrow specialization, it is necessary to say this to customers, because it means better service in the niche market.

When designing benefits, all the features of the business are important, so it's important to mention them. This could be the use of certain technology or equipment, an assortment of products that exceed competitors' assortment, the purchase of raw materials in Europe, and so on.

And, of course, one should not forget about achievements. Diplomas, certificates, a list of partner companies and large client companies with their logos work as social proof, which has credibility in the company and is the main goal of competitive advantages. With the help of documents that you need to demonstrate to your potential customers, you can emphasize your experience, status, authority. And this is very important for buyers, as it shows that the company is working for the future, developing. 
Companies that work in a very competitive niche, or start-up companies are more interested in advantages that, in contrast to the previous ones - natural ones, are called artificial. First of all, this is an additional value, that is, to offer your client something that competitors do not offer. For example, when buying a phone - an accessory as a gift. In other words, any, even the most ordinary, action will help create an advantage over competitors and attract the attention of buyers.

Such an advantage as responsibility for a product (service) works well. For example, if the seller assumes the responsibility to claim that the period of his product use is 10 years. Buyers will respond to such an offer in case of strong evidence.

An important competitive advantage is the guarantee for the product, service. For example, providing the possibility of returning and exchanging goods within 30 days, despite the fact that, by law, this can be done only within 14 days. Or guarantee a refund if the service fails.

An interesting approach, called the "demonstration of the proposal." Its essence is as follows: if a product or service does not have obvious advantages (which is quite common), then you can simply show the potential customer what he is offered in the form of a demonstration. If this is a product, then you can shoot a video about its appearance to show a person how he really looks. If the service is the process of its implementation. Based on the fact that a person perceives $85 \%$ of information visually, demonstration of the video clip will be a significant advantage for the company.

The real customer reviews are also important: video, text, where real consumers express their opinion about the company, product or service, which is social proof, a reason for trusting the company and its activities.

As noted above, it is not always possible to develop natural competitive advantages, especially in very popular and saturated niches. The only way out in this case is to create false (false advantages), there are those that work on the 
emotions and beliefs of the consumer, the company, product, service is unique. For example, in an advertisement for Jacobs coffee it was announced that it was "the magic of aromavelvet," that is, the magic of velvet aroma. The concept "aromavelvet" does not exist in nature, but such a unique selling proposition of the brand has become its most important advantage.

Not all companies, especially young ones that are just entering the market, can compete with their competitors. To stay afloat, they have to raise prices, extend the delivery time through a logistics department and the like. All this can negatively affect the business, pushing away customers, because no one wants to pay more or wait longer for their order, when the competition is much cheaper and faster. In such cases, special techniques are used that help to make advantages with the disadvantages. These are facts that counterbalance weaknesses.

For example, the inconvenient location of the office, or far from the center, is the disadvantage of any business. In this case, the counterargument is that the company's office has a showroom where you can see the goods with your own eyes; the warehouse is located on the territory; There is a convenient parking place, including for freight vehicles. There is the possibility of selfdelivery and delivery throughout the city.

The next possible drawback is the price is much higher than in competitors' stores. In contrast, a computer company, for example, can offer additional features: updated to the latest version of the operating system, a cover, headphones and a protective glass as a gift.

The disadvantage is the long delivery of the order. Counterargument - the ability to order spare parts from the manufacturer without intermediaries, the ability to order rare spare parts.

If a young company just appeared on the market, the lack of work experience is perceived by consumers with caution and some distrust. In this 
case, you can offer the shipment of goods on the day of order by Ukrposhta, Nova Poshta, free consultations, without prepayment.

Newly created companies usually have a small set of goods and services, which is an objective factor. In contrast to this argument, one can offer a statement about narrow specialization on a particular brand and the possibility of providing detailed advice on the specifics of the product.

Thus, even those shortcomings that can lead the company to failure can become powerful competitive advantages that even firms already established in the market are not able to provide to customers.

Conclusions. In the face of increased competition, one of the main means of promoting your business, strengthening competitive positions in the market is to demonstrate to consumers the advantages of the company, product or service and the benefits that they will receive as a result. Competitive advantages can be provided by price, delivery time, experience, conditions of cooperation, narrow specialization, business features, achievements, added value, responsibility for the product (service), guarantee, demonstration of the offer, real customer reviews and the creation of so-called false (erroneous) preferences, working on the emotions and beliefs of the consumer, the company, product, service is unique.

Demonstration of competitive advantages is a fairly simple option to promote and position your name, does not require financial investments, but it is an effective tool for conducting competition. Therefore, only working on your competitive advantages, in the future you can take a leadership position in your niche.

\section{REFERENCES}

1. Porter, M. (2010). Konkurentsiya. [Competition]. M.: Vilyams [in Russian]. 
2. Lamben, Zh. Zh. Strategicheskiy marketing: evropeyskaya perspektiva. [Strategic marketing: a European perspective]. Retrieved from: http://polbu.ru/lamben [in Russian].

3. Azoev, G.L. \& Chelenkov, A.P. (2010). Konkurentnyie preimuschestva firmyi. [Competitive advantages of the company]. M.: Novosti [in Russian].

4. Balabanova, L. V. \& Kholod, V. V. (2006). Marketynhove upravlinnia konkurentospromozhnistiu pidpryiemstv: stratehichnyi pidkhid: monohrafiia [Marketing Management of Enterprise Competitiveness: Strategic Approach: Monograph]. - Donetsk: Don DUET im. M. Tuhan-Baranovskoho [in Ukrainian].

5. Maslak, O. I., Kviatkovska, L. A. \& Bezruchko, O. O. Vyznachennia rivnia konkurentnoi perevahy mashynobudivnoho pidpryiemstva na zasadakh zabezpechennia rozvytku yoho ekonomichnoho potentsialu [Determination of the competitive advantage level at the machine-building enterprise on the basis of ensuring its economic potential development]. Retrieved from: http://www.economy.nayka.com.ua/?op=1\&z=3174 [in Ukrainian].

Стаття надійшла до редакиії 07.03.2020

(C) Pavlovska Liudmyla 